\title{
Production of Abrasive Sandpaper using Periwinkle Shells and Crab Shells
}

\author{
Ambali Ibrahim Owolabi, Shuaib-Babata Yusuf Lanre, Abdulqadir Lawal Babatunde, Ibrahim \\ Hassan Kobe, Aremu Ishaq Na'allah and Ibraheem Taofeek Olawale
}

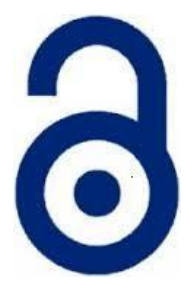

\author{
Received: 24 April 2020 \\ Accepted: 15 May 2020 \\ Published: 30 June 2020 \\ Publisher: Deer Hill Publications \\ (c) 2020 The Author(s) \\ Creative Commons: CC BY 4.0
}

\begin{abstract}
In this study, the properties of periwinkle shell and crab shell grains, such as hardness, compressive strength and wear resistance were examined for their suitability as abrasive materials. The binding effect of polyester resin at high concentration was also considered. Through the process of crushing, grinding and subsequently sieving using ASTM E11 set of sieves, the shells were processed into grit standards grain sizes of P40 and P60. Furthermore, by mixing and mould compression using a hydraulic press polymer matrix composite with particles varying from 96 wt. $\%$ to 92 wt. $\%$ and resin 3 wt.\% to $7 \mathrm{wt} . \%$ with $1 \mathrm{wt} . \%$ each of cobalt naphthalene and methyl ethyl ketone peroxide hardener respectively were developed from the grits. It was found that, with an increase in polyester resin content, the hardness and compressive strength increased, while the wear rate decreased. The composition with $92 \mathrm{wt} . \%$ periwinkle shell grains to $7 \mathrm{wt}$.\% polyester resin was found to be with the most improved abrasive properties.
\end{abstract}

Keywords. Abrasive properties, Periwinkle shell, Crab shell, Wear Rate

\section{INTRODUCTION}

In shaping, finishing and polishing of other materials, abrasive materials which are very rigid mineral materials are used. The abrasive materials are processed in a furnace after which they can further be crushed and sifted into different grain sizes called grits [1]. Hardness, brittleness, character of fracture, toughness, grain shape and grain size, purity and uniformity of the grains are considered as the most significant physical properties of abrasive materials [2].

Sandpaper is an abrasive grain material that is used to make the surface of work-piece smoother or rougher if rubbed with the surface of the work-piece. Small amounts of the work-piece surface materials are removed in the process. This is useful in removing unwanted layer or coating, such as dirt, paint and stain, on surface of a material [3-4] to attain precision and good surface appearance. Sandpaper consists of abrasive grain material fixed to a flexible backing material by an adhesive [5].

In Nigeria, available synthetic materials abrasive materials are either very scarce or very expensive; this is mainly due to non-availability or high cost of the materials (such as silicon carbide, aluminium oxide and aluminium silicate) used in their production [6]. Meanwhile, the available natural materials, like lime, chalk and silica, aluminium silicate, kaolinite, diamond and diatomite are found to be less effective due to impurity nature of the materials [7-8]. In developing countries like Nigeria, bio-wastes (such as shells from crabs, periwinkles, snails, etc) which are from biological organisms are dumped indiscriminately and as such results to environmental nuisance. Thus, the need to convert these bio-wastes into industrial tools like sandpaper are essential for economic development and sustainability, which will assist in addressing the most needed economic diversification in Nigeria to quench the effect of COVID-19 on the nation's economy.

Periwinkles are marine molluscs (gastropods) with thick spiral shells. The Periwinkle shells are the outer casing of the sea snails which are hard with swollen rough surfaces and usually regarded as waste after consuming the inner fleshy part of the snail. As they grow, gastropod shells follow a mathematically ordered pattern. Thus, as they increase in size, they retain their basic form. It is the presence of the high level of concentration of calcium carbonate (CaCO3) that makes the shell hard. In an experiment on the chemical content of the periwinkle shell and its suitability in thin layer cinematography carried out by Orji et al. [9], the shells were found to contain very high percentage of $\mathrm{CaCO} 3$,

\footnotetext{
I. O. Ambali', Y. L. Shuaib-Babata'®, H. K. Ibrahim², L. B. Abdulqadir³, N. I. Aremu', and T. O. Ibraheem 'Department of Materials \& Metallurgical Engineering, University of Ilorin, Ilorin, Nigeria

2Department of Mechanical Engineering, University of Ilorin, Ilorin, Nigeria

${ }^{3}$ Department of Mechanical Engineering, Kwara State Polytechnic, Ilorin, Nigeria

E-mail: sylbabata@unilorin.edu.ng
}

Reference: I. O. Ambali, Y. L. Shuaib-Babata, H. K. Ibrahim, L. B. Abdulqadir, N. I. Aremu, and T. O. Ibraheem (2020). Production of Abrasive Sandpaper using Periwinkle Shells and Crab Shells. International Journal of Engineering Materials and Manufacture, 5(2), 55-61. 
thereby making them a probable source of $\mathrm{CaCO}$. The high content is responsible for it being considered for the experiment.

Crabs are crustaceans that are not readily available to people around landlocked areas, but available in high quantities in coastal areas. The swimming crab, Callinectesamnicola is an important food item in coastal waters of West Africa. It belongs to the phylum arthropoda, order decapoda and family portunidae. Crabs are high in calcium; potassium, magnesium, and manganese which make them possess hard and rigid exoskeleton [10]. Other functions of this mineral include formation of endoskeleton structure and maintenance of colloidal system. The crab shell contains $40-70 \%$ calcium carbonate which varies according to the species; the calcium carbonate can be further processed into calcium hydroxyapatite [11].

In engineering applications, these sea shells are being used as substitutes for aggregates (chippings) especially in the coastal areas where aggregates are lacking. Some researchers have conducted exploratory studies on the partial or total substitution of waste sea shells with coarse aggregate for the production of mortar and concrete used for civil construction. In the study carried out by Adewuyi and Adegoke [12], it was found that the replacement of granite with $35.4-42.5 \%$ waste periwinkle shells did not compromise the compressive strength of the resulting concrete and made 14.8 - $17.5 \%$ saving in material cost. In glass manufacturing, the suitability of periwinkle shells as a substitute for lime was examined by Malu and Bassey [13]. A proximate analysis of periwinkle shell by Malu and Bassey showed that the shell contained Calcium oxide (38.4\%), Silicon (IV) Oxide (0.014\%), Magnesium Oxide (18.70\%), Aluminium Trioxide (0.211\%) and Iron Oxide $(0.019 \%)$ which are important minerals suitable for glass production [13]. Emery cloth/sandpaper was manufactured from locally sourced materials by Wai and Lily [14]. Silicon sand (quartz) which was sieving into fine grit $180 \mu \mathrm{m}$ and coarse grit $50 \mu \mathrm{m}$ was used as abrasive grit with epoxy resins as binder to produce sandpaper using Hand Spray method. The researchers recommended the manufacturing process for small scale industries. Kishore also worked on the investigation of mechanical properties of crab shell. The results of the study showed that under tensile loading conditions, the whole crab shell exhibited a mode of fracture which does not include the delamination of lamellae common to the other arthropods [15].

It is of interest to further study some properties of periwinkle shells and crab shells and also to determine its usefulness and relevance in engineering usages, especially in production of abrasive material. Therefore, the use of periwinkle and crab shells which are regarded as waste products were considered for production of abrasive sandpaper in this study. This will help to domesticate production of sandpaper in Nigeria; assist in economic diversification of the nation through establishment and sustainability of Small and Medium Scale Enterprises (SMSE); and adequately proffer sustainable solution to the issue of unemployment among the nation's youths; and economic down turn that may arise as results of COVID-19 lockdown.

\section{METHODOLOGY}

\subsection{Materials Preparation}

The periwinkle and crabs were commercially obtained in a market at Egbeda, Lagos State, Nigeria. The periwinkle and crabs shells (Figures $1 \mathrm{a} \& \mathrm{~b}$ ) were removed and washed in water to remove all traces of dirt on them. Approximately $3.5 \mathrm{~kg}$ samples of shells were sun dried for 2 weeks and further oven dried till moisture content was fully removed. The dried samples were further charged into a local grinding machine where they were ground into powder. The powdery materials were then separately sieved (using ASTM E11 guidelines) with two sieve sizes of 250 $\mu \mathrm{m}$ (P60 abrasive grits) and $420 \mu \mathrm{m}$ (P40 abrasive grits) [16-17]. Other substances used in this study, which include cobalt naphthalene, methyl ethyl, ketone peroxide and polyester resin were classified and labelled for easy identification. Figures 2 (a \& b respectively) show the periwinkle shell grain sieved to size of $250 \mu \mathrm{m}$ and $420 \mu \mathrm{m}$; while the samples of crab shell grain sieved to size of $250 \mu \mathrm{m}$ and $420 \mu \mathrm{m}$ are presented in Figures 3 (a \& b respectively).

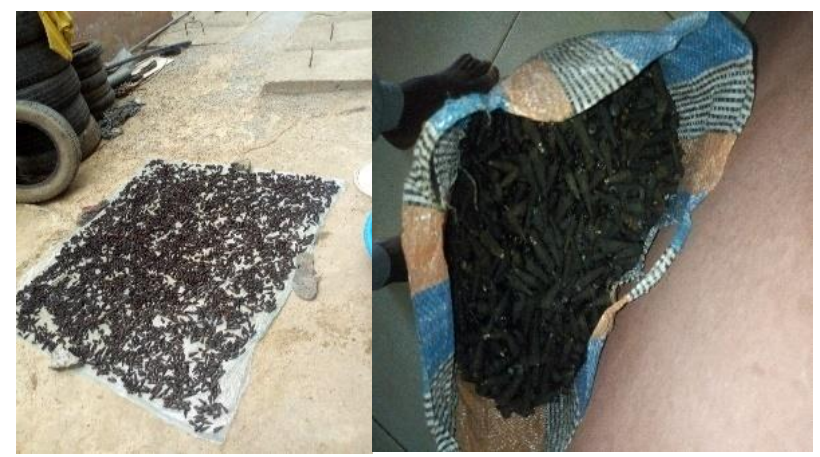

(a) Periwinkle Shells

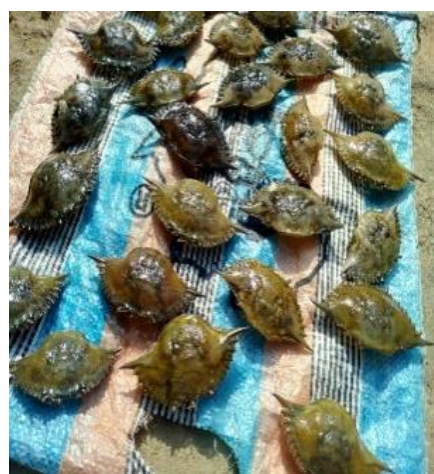

(b) Crabs

Figures 1: Samples of the periwinkle shells and crabs used in this study 
Table 1: Grains/resin composite formulation in batches

\begin{tabular}{llll}
\hline & Weight Percentage composition (\%) & \\
\hline Shell Grains & 96 & 94 & 92 \\
Polyester Resin & 3 & 5 & 7 \\
Accelerator & 1 & 1 & 1 \\
MEKP Catalyst & 1 & 1 & 1 \\
Total Composition & 100 & 100 & 100 \\
\hline
\end{tabular}

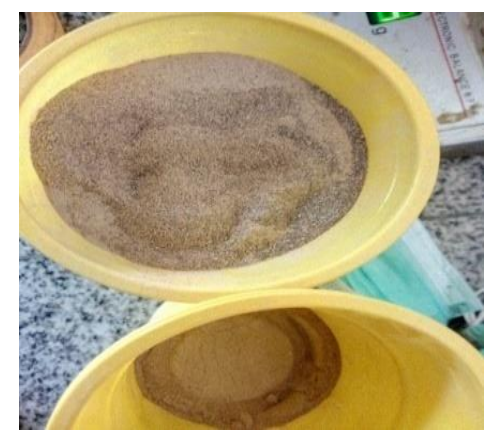

Figure 2a: Sample of periwinkle shell grains $(250 \mu \mathrm{m})$

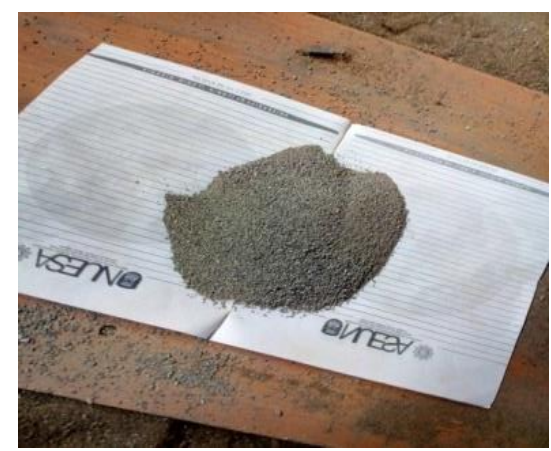

Figure 2b: Sample of periwinkle shell grains $(420 \mu \mathrm{m})$

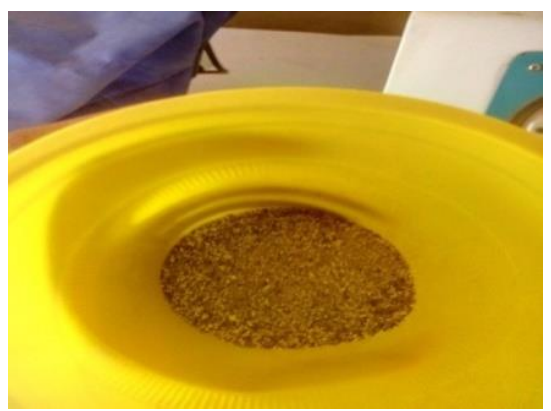

Figure 3a: Sample of crab shell grains $(250 \mu \mathrm{m})$

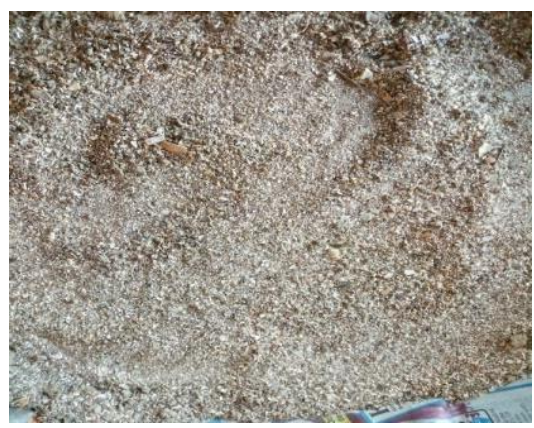

Figure 3b: Sample of crab shell grains $(420 \mu \mathrm{m})$

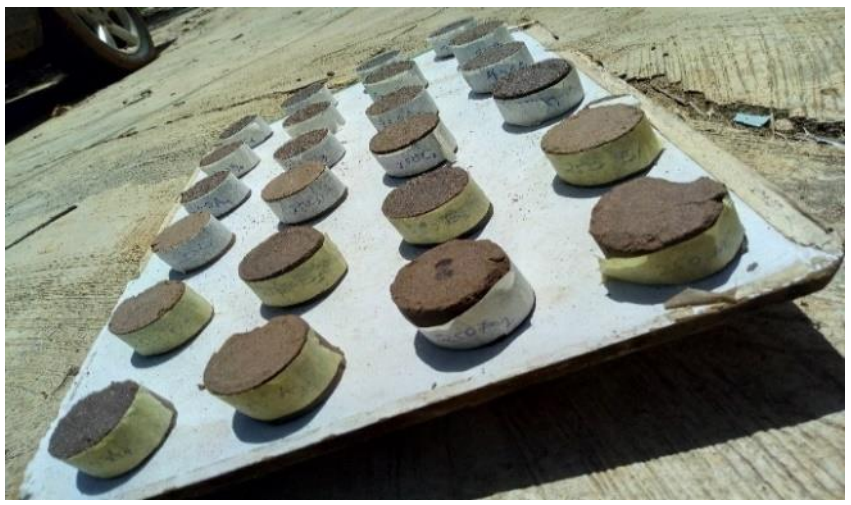

Figure 4: Some Samples of the Specimens

Periwinkle shell and crab shell of $118.0 \mathrm{~g}, 114.0 \mathrm{~g}$ and $111.6 \mathrm{~g}$ (in equal percentage, that is $50 \%$ each of the total grams) were measured using an electronic weighing balance (HX 302T with $0.01 \mathrm{~g}$ accuracy), which corresponds to $96.0 \mathrm{wt} . \%, 94.0 \mathrm{wt} . \%$, and $92.0 \mathrm{wt}$ \%. A measure of polyester resin in $5.4 \mathrm{~g}, 7.2 \mathrm{~g}$ and $9.6 \mathrm{~g}$ which corresponds to $3.0 \mathrm{wt}$. \%, $5.0 \mathrm{wt}$. \% and $7.0 \mathrm{wt}$. \% was separately weighed out. To bring a balance of $100 \mathrm{wt}$. \% in material composition, $1.2 \mathrm{~g}$ of catalyst and $1.2 \mathrm{~g}$ of accelerator were measured.

The test samples were produced from each of the weight composition of resin by compressing the pastes to solid shapes in a metal mould of dimensions height $30 \mathrm{~mm}$ and diameter $52 \mathrm{~mm}$ using a hydraulic press (Model P100T Capacity, Serial No-38280). The samples were kept in a well-aerated environment for 21 days as practiced by lbrahim et al. [6]. Some of the samples produced from the formulation are presented in Figure 4, while Table 1 shows the formulation used in production of sandpaper samples. 


\subsection{Samples' Characterization}

The samples of the sandpapers produced were characterized through determination of some of the samples' physical and mechanical properties, such as water absorption, wear rate, hardness and strength.

\subsubsection{Water Absorption Test}

The water absorption test was carried out by determining the weight of the sample (Wo) using weighing machine and subsequently placed the sample in a contained containing water. It was re-weighed after 24 hours to obtain Wi. For each sample, the percentage weight gained was calculated and recorded using the following relationship in Equation 1 [18].

\subsubsection{Hardness Test}

The hardness value of the composite of different grain sizes was determined by the Brinell hardness method using a Testometric Materials Testing Machine (Type DBBMTCL-5000 Kg, Serial No. 17819) at National Centre for Agricultural Mechanization Universal Testing Machine (NCAM UTM) Laboratory, llorin, Nigeria, based on ASTM E10-18 guidelines [19]. A $10 \mathrm{~mm}$ steel ball indenter was pressed with the specimen at a test speed of $5 \mathrm{mins}$ using a force load of 50kg to a penetration depth. The Brinell hardness number was calculated using Equation 2.

\subsubsection{Compressive Test}

The compressive strength test was carried out using the Testometric Materials Testing Machine (Type DBBMTCL$5000 \mathrm{Kg}$, Serial No. 17819) at National Centre for Agricultural Mechanization Universal Testing Machine (NCAM UTM) Laboratory, Ilorin, Nigeria, based on ASTM Standards C 617 guidelines [20].

\subsubsection{Wear Test}

The wear test was carried out at using Europec Bench Grinder (MD-250F). The grinding wheel was coated with an abrasive material and a load of $2 \mathrm{~kg}$ was applied on each of the specimens for 2 minutes at $2950 \mathrm{rev} / \mathrm{min}$. The differences in weight measured before and after tests give the wear of the samples. The formula (Equation 3 ) used to convert the weight loss into wear rate as practiced by Bashar et al. and Edokpia et al., [21-22]:

$$
\begin{aligned}
& \text { (\%) weightgained }=\frac{W i-W o}{W o} \times 100 \% \\
& \mathrm{BHN}=\frac{2 \mathrm{~F}}{\pi \mathrm{D}\left[\mathrm{D}-\sqrt{ }\left(\mathrm{D}^{2}-\mathrm{d}^{2}\right)\right]}\left(\mathrm{Kg} / \mathrm{m}^{2}\right) \\
& W=\frac{w x-w y}{s}=\frac{\Delta w}{s}
\end{aligned}
$$

Where $W i=$ weight after immersion and $W o=$ weight before immersion, $\mathrm{F}=$ Applied load in $\mathrm{Kg}, \mathrm{D}=$ Diameter of indenter in $\mathrm{mm}, \mathrm{d}=$ Diameter of indentation in $\mathrm{mm}, \mathrm{wx}$ is the weight before the test, wy is the weight after the test and $s$ is the sliding distance.

\section{RESULTS AND DISCUSSIONS}

\subsection{Water Absorption Test}

The results of the water absorption test are presented in Figures 5. The results showed that the water absorption rate in the developed abrasive sandpaper samples increased as the sieve size increased from $250 \mu \mathrm{m}$ to $420 \mu \mathrm{m}$ in the formulation. The increase in water absorption rate must have been due to the poor interfacial bonding between binder and filler particle that caused increase in porosity.

The highest water absorption value for the $250 \mu \mathrm{m}$ particle size was $5.21 \%$ as against the $420 \mu \mathrm{m}$ particle size which showed a highest value of absorption rate of $13.186 \%$. The composites with low resin concentration are prone to water absorption due to poor interaction of grains surface area and the resin binder [22]. This shows better water absorption property than the produced abrasive sandpaper. From this result, $420 \mu \mathrm{m}$ particle size of abrasive sandpaper shows better water absorption rate compared to $250 \mu \mathrm{m}$ particle size. This result is in line with result obtained by Obot et al. [23].

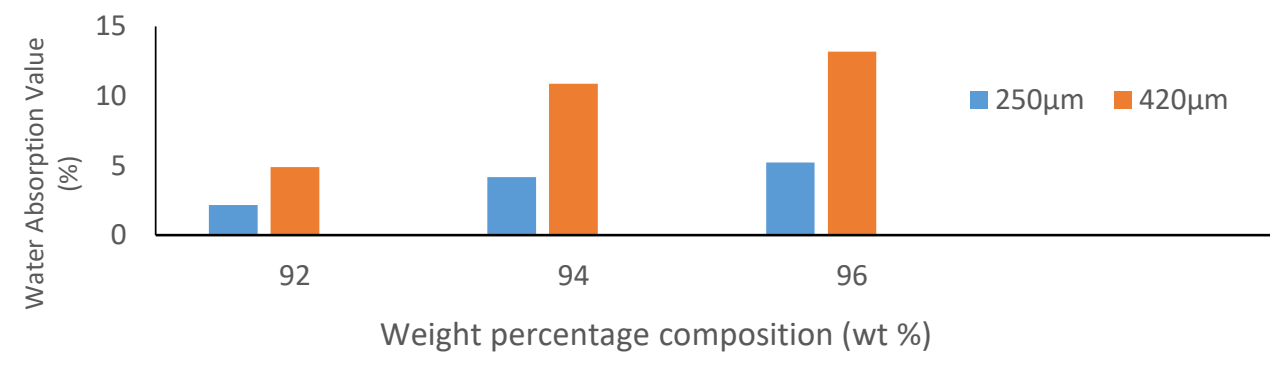

Figure 5: The sandpaper samples' water absorption values 


\subsection{Hardness Test}

Figure 6 shows the results of the Brinell hardness test carried out on the samples made from $250 \mu \mathrm{m}$ and $420 \mu \mathrm{m}$ sieve sizes. The results indicated that there was an increment in the hardness value with increasing polyester resin concentration from $3 \mathrm{wt}$. \% to $7 \mathrm{wt}$.\%. The results for Brinell hardness tests carried out on the abrasive samples showed that the hardness values increased proportionally as the percentage weight composition of the polyester resin increased from 3 to $7 \mathrm{wt}$. \%. Interfacial bonding of the polyester resin holding the periwinkle shell and crab shell grain particles together was responsible for the increase in hardness, and also contributes to the hardness of the parent composite material [ ]. The samples displayed the hardness increment across the sieve size with hardness values of $18437.263 \mathrm{~kg} / \mathrm{m}^{2}$ and $21650.901 \mathrm{~kg} / \mathrm{m}^{2}$ for $250 \mu \mathrm{m}$ and $420 \mu \mathrm{m}$ sieve sizes with $7 \mathrm{wt}$. \% polyester resin respectively. In line with the findings of Obot et al., the samples' hardness increased with reducing particle sizes [24].

\subsection{Wear Test}

The results of the wear test carried out for 2 minutes per specimen with a fixed applied load of $2 \mathrm{~kg}$ are as presented in Figure 7. It was observed from the results that the $250 \mu \mathrm{m}$ grain sample has the least wear rate $\left(1.67 \mathrm{~m}^{3} / \mathrm{Nm}^{2}\right.$ with a resin content of $92 \mathrm{wt} \%$. It was also observed that the wear rate decreased with increasing resin content which is due to an increase in hardness value and compressive strengths of the samples. The relationship between compressive strength, hardness and wear resistance with increased polyester resin content is in agreement with the assumptions of previous researchers $[6,25-27]$. The decrease in wear rate with increased in the resin content may be also be attributed to the interfacial bonding between the resin and the grains. Therefore, the wear properties of the agrowaste sandpaper can be improved by increasing the polyester resin content. From the results (Figure 7), it can be proposed that the $250 \mu \mathrm{m}$ sample with $1.67 \mathrm{~m}^{3} / \mathrm{Nm}$ wear rate is an alternative for the common sandpaper.
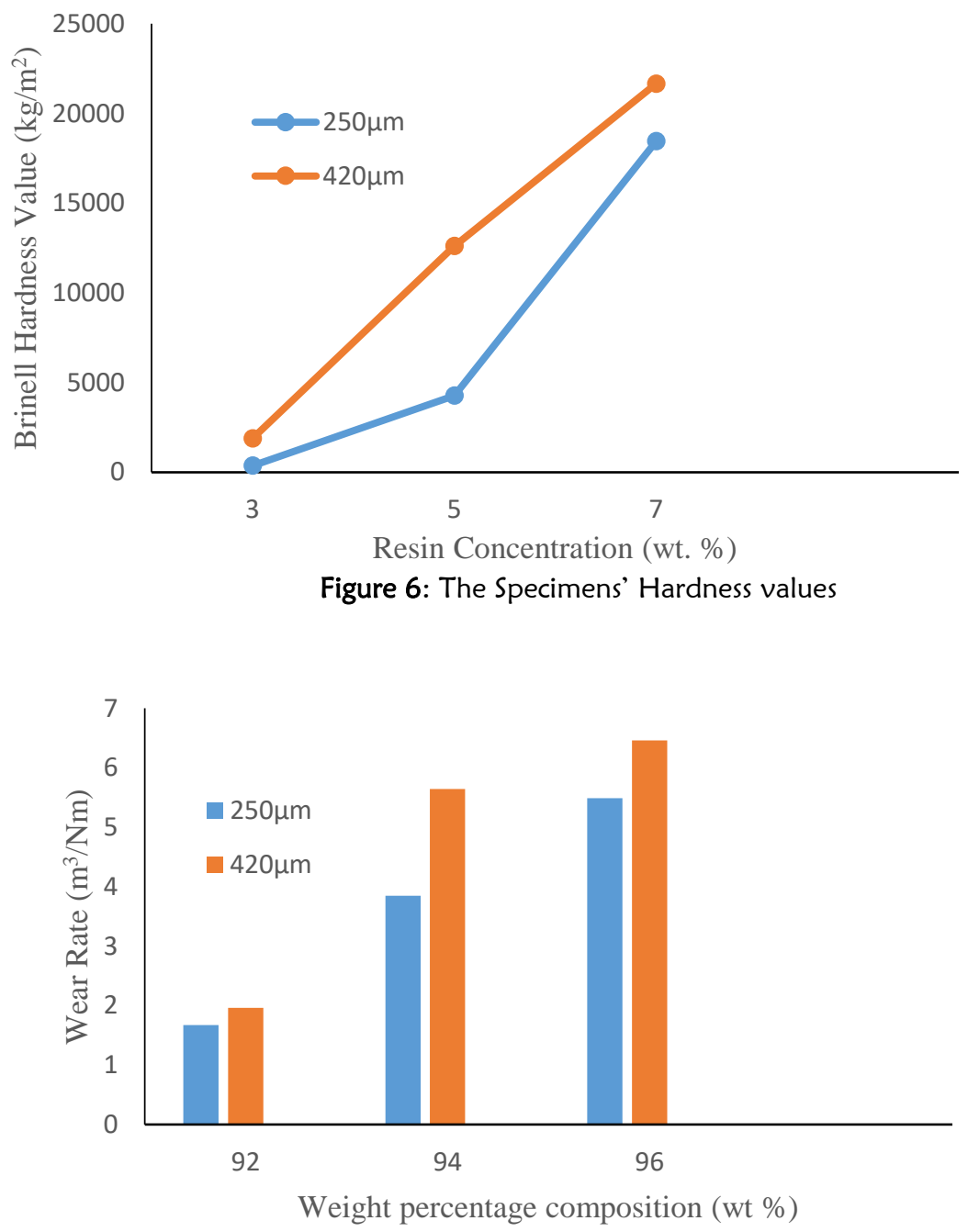

Figure 7: The Specimens' Wear Rates 


\subsection{Compressive Test}

The compressive strength test results in Figure 8 shows the compressive strength across the sieve sizes. The $250 \mu \mathrm{m}$ sieve size of the produced samples displayed the lowest compressive strength $\left(1.650 \mathrm{~N} / \mathrm{mm}^{2}\right.$ and $39.869 \mathrm{~N} / \mathrm{mm}^{2}$ for $3 \%$ and $7 \%$ resin composition respectively) while the other sieve size of $420 \mu \mathrm{m}$ displayed compressive strength of $16.429 \mathrm{~N} / \mathrm{mm}^{2}$ and $45.477 \mathrm{~N} / \mathrm{mm}^{2}$ for $3 \%$ and $7 \%$ resin composition respectively. This may be due to the powder fineness inducing brittleness upon the composite as seen by the reduced strength with reducing sieve sizes. There was an increase in the compressive strength with increasing polyester resin concentration from 3 to $7 \mathrm{wt}$. \%. The highest ultimate compressive strengths obtained was $45.477 \mathrm{~N} / \mathrm{mm}^{2}$ for $420 \mu \mathrm{m}$ particle size of shells with 7 wt. \% polyester resin and $39.869 \mathrm{~N} / \mathrm{mm}^{2}$ was recorded for $250 \mu \mathrm{m}$ particle size with $5 \mathrm{wt}$.\% polyester resin.

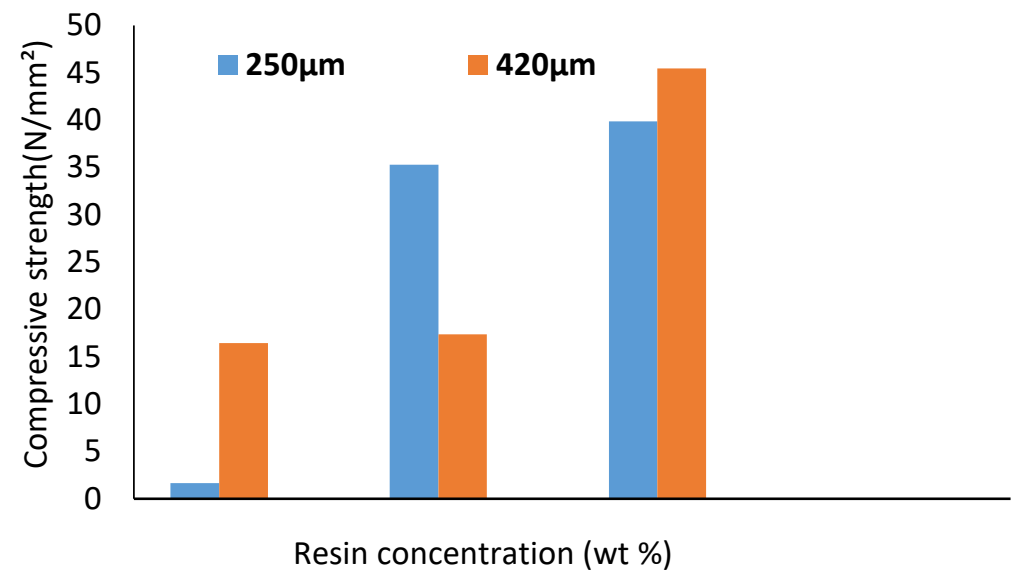

Figure 8: The Specimens' Compressive Strengths

\section{CONCLUSIONS}

From the results and discussion of the results, the following conclusions were drawn:

1. The properties of each of the samples varied as a result of the different mixing ratio of the grains composition and resin concentration.

2. Calcium oxide largely dominated the composition of the periwinkle shell grains with concentration approximately $90 \%$. Under compressive stresses, the grains were liable to distortion and grain disorientation.

3. The periwinkle/polyester resin composite's hardness and compressive strength increased gradually with increase in the resin's concentration from 3 to $7 \mathrm{wt}$. \%. Meanwhile, with increased in the resin concentration and reduction in grains composition, the wear reduced. Interfacial bonding between the combination of periwinkle grains and crab shells with polyester resin attributed to the improvement in the tested properties of the composite.

4. The composition from $92 \mathrm{wt} . \%$ and resin at $7 \mathrm{wt} . \%$, and $1 \mathrm{wt} . \%$ for methyl ethyl ketone peroxide hardener and cobalt naphthalene each exhibited the most suitable abrasive properties (such as hardness, wear resistance and compressive strength) considered as the appropriate alternative material for abrasive sandpaper production.

5. The properties of the agro-waste sandpaper exhibited possible applications as abrasive grits with further improvement.

\section{RECOMMENDATIONS}

From the outcomes of this study, it is recommended that:

1. Periwinkle shells and crabs shells can be used to convert waste to wealth.

2. Since the performance evaluation of the produced abrasive paper was suitable for usage, the importation of sandpaper from other countries into Nigeria can be greatly reduced by producing the abrasive locally using agricultural wastes.

3. Further research works can be carried out to discover hitherto waste materials that could be recycle for meaningful purposes rather than disposing them off. 


\section{REFERENCES}

1. Atia, M. R. and Maksoud, T. M. A. (2004). Review of intelligent grinding and dressing operations. Journal of Machining Science and Technology, 8, 263-276.

2. Oyawale, F. A. and Odior, A.O. (1998). Manufacture of abrasive paper from locally sourced raw materials in Nigeria. Journal of Emerging Trends and Applied Sciences, 1(1), 40-47.

3. Odior, A. O. and Oyawale, F. A. (2010). Manufacture of abrasive grains from locally sourced raw materials in Nigeria, Journal of Emerging Trends in Engineering and Applied Sciences (JETEAS), 1(1), 40-47

4. Obot, M. U., Yawas, D. S., Aku, S. Y., Obada, D. O. (2016). An assessment on the production of abrasive sandpaper from locally sourced materials, Tribology in Industry, 38(2),176-185

5. Aku, S., Yawas, D., Madakson, P., \& Amaren, S. (2012). Characterisation of Perinwinkeshell as asbestors-free brake pad materials. Pacific Journalof Science and Technology, 13(2), 57-63.

6. Ibrahim H.K., Abdulhamid, A.S., Abdulkareem, S., Shuaib-Babata, Y.L., Popoola O.T., Kareem, A.G., Adeyi A. M., Busari, O.Y., Ambali, I.O. (2019). Development of abrasive sandpaper grains from agro-waste material for polishing of wood surface. Adeleke University Journal of Engineering and Technology, 48-60.

7. Eckart, K., \& Aku, S. (2013). Development of an abrasive material using periwinkle shells. Journal of King Saud University of Engineering Science, 5(3), 23-37.

8. Scott, I. (2010). Tribology of abrasive machining process. William Andrew Publishing, 268.

9. Orji B., Igbokwe, G. E., Anagonye, C. O. (2017). Chemical content of the periwinkle shell and its suitability in thin layer chromatography. International Journal of Chemistry Studies, 09-11.

10. Elegbede, I.O. and Fashina-Bombata, H.A (2013). Proximate and mineral compositions of common crab species (callinectespallidus and cardisomaarmatum). Journal of Poultry, Fisheries and Wildlife Sciences, 2, 1-5.

11. Indah R., Erna M., Afdaliah Y., Muhammad, S. ad Andi, I. L. (2015). Synthesis and characterizations of calcium hydroxyapatite derived from crabs shells and its potency in safeguard against to dental demineralizations. Internal Journal of Biomaterials, 1-8.

12. Adewuyi, A.P and Adegoke, T. (2008). Exploratory study of periwinkle shell as coarse aggregate in concrete works.Journal of Science Resources, 1678-1681.

13. Malu, S.P and Bassey, G.A (2003). Periwinkle (T. Fuscatus) shell as alternative source of lime for glass industry. Global Journal of Pure and Applied Sciences, 491-494.

14. Wai, J.J. and Lily, M.T (2002). Manufacturing of emery cloth from local raw materials. Global Journal of Engineering Research, 31-37.

15. Kishore Kumar Gadgey, D. A. (2017). Investigation of mechanical properties of crab shell: A Review. International Journal of Latest Trends in Engineering and Technology, 268-281.

16. ASTM E11-17, Standard specification for woven wire test sieve cloth and test sieves, ASTM International, West Conshohocken, PA, 2017, www.astm.org

17. FEPA Abrasives, 2013. P-grit sizes coated abrasive products. Retrieved August 18, 2019 at 08:50 from <http://www.fepaabrasives.com/>

18. Aigbodion, V. S., Akadike, U., Agunsoye, J. O. (2011). Development of asbestos-free brake pad using bagasse. Tribology in Industry, 32. 12-18.

19. ASTM E10-18 - Standard test method for brinell hardness of metallic materials, ASTM International, West Conshohocken, PA, 2018, www.astm.org.

20. ASTM C617 / C617M-15, Standard Practice for Capping Cylindrical Concrete Specimens, ASTM International, West Conshohocken, PA, 2015, www.astm.org

21. Bashar, T., Da Asabe, G., Peter, K., Madakson, B., Joseph, F., \&Manji, K. (2012). Material selection and production of a cold worked composite brake pad. World Journal of Engineering, 2(3), 96.

22. Edokpia, R., Aigbodion, V., Obiorah, O., \& Atuanya, C. (2014). Evaluation of the properties of eco friendlybrakepad using egg shell particles. E. R. Producer, \& Gum Arabic Science Direct.

23. Obot, M.U, Aku, S. Y,Yawas D. S., Obada, D.O (2017). An assessment on the production of abrasive sandpaper from locally sourced materials. Journal of King Saud University - Engineering Sciences, 284-288.

24. Obot, M., Yawas, D., \& Aku, S. (2015). Development of Abrasive Using Periwinke Shells. Journal of King Saud University of Engineering Sciences. 1-5.

25. Marinescu, I.D., Rowe, W.B., Dimitrow, B., Inasaki, I., (2004). Tribology of Abrasive Machining Process, first ed. William Andrew Publishing, 268.

26. Aigbodion, V., Akadike, U., Hassan, S., \& Asuke, F. A. (2010). Development of Asbestors free brake pad using bagasse. Tribology in Industry, 32(1), 12-17.

27. Yawas, D., Aku, S., \&Amaren, S. (2013). Morphorlogy and Properties of Periwinkle Shells Asbestors-free Brakepad.Journal of King Saud University of Engineering and Technology. 32(1), 